Article

\title{
The Legacies of Bindy Johal: The Contemporary Folk Devil or Sympathetic Hero
}

\author{
Manjit Pabla \\ Sociology and Legal Studies, The University of Waterloo, Waterloo, ON N2L 3G1, Canada; \\ m49singh@uwaterloo.ca
}

Received: 18 January 2020; Accepted: 4 May 2020; Published: 5 May 2020

\begin{abstract}
A folk devil has the ability to elicit a community's fear over crime. Notorious late gangster, Bindy Johal, occupies this position as his legacy stirs the social anxieties over gang violence by some in the Punjabi-Sikh community in Western Canada. A competing narrative of Johal's legacy has emerged, which frames him in a more sympathetic light, and as an individual who overcame systemic racial barriers that subordinated the masculinity of South Asian men in British Columbia. Based on interviews with 34 authorities in the Lower Mainland of British Columbia, and drawing attention to his status as both a folk devil and hero, the discussion reveals two dueling narratives framing his legacy. The overall effect of these contradictory narratives is the overshadowing of racism, class oppression and a regional history within Sikh extremist movements that illustrate why gang involvement may appeal to some disenfranchised boys and men in the Indo-Canadian community.
\end{abstract}

Keywords: masculinities; gangs; British Columbia; moral panics; Sikhs; Punjabis; Khalistanis

\section{Introduction}

"Every grade $8 \mathrm{kid}$ is talking about [Bindy] as he is some hero who defied the police and got killed and his interviews are online and people are looking it up, and these grade 6,7 kids are always searching them up and bringing him up. So, one thing I decided is never, ever use his name or react to his name" -(Simran (secondary school teacher), interview, 1 December 2016)

"When we sit down and think about race relations in this country and our community, shit we look at people like fucking Bindy and say: "hey. Did he do something for our community?" Did he? Like moralism aside, put the ethical, moral shit [aside], let's just deal with power relations. And so, when you look at South Asian young men today, this guy becomes fucking icon. He becomes a fucking God in the imagination of the emasculated South Asian male. All of a sudden, they're like "oh right. We can fucking do this"” —(Diljit (former gang member), interview, 15 August 2016)

In the Lower Mainland of British Columbia (BC) the name of late gangster "Bindy Johal" polarizes a community dealing with a perceived problem of gang involvement of Punjabi youth. On the one hand, Johal occupies the position of a 'folk devil', the classical criminological construct that has the ability to stir a community's social anxiety and fuel a moral panic on gangs in the region. Specifically, Johal is posthumously blamed for recruiting a large number of Sikh-Punjabi youth to gangs, as claimed by authorities. Yet Diljit, a former gang member, frames the legend of Johal as a folk hero of sorts, or at the very least a sympathetic figure who has been romanticized or idolized by a generation of disenfranchised youngsters. Under this conception of his legend, Johal is believed to have broken through a pervasive system that has subordinated the masculinity of South Asian males. 
The dominance of Sikhs in the region at the time through the Khalistani movement coincides with Johal's own rise to power as a gang leader, as well as the involvement of other Sikh-Punjabi youth in gangs. These individuals transformed to modern-day soldiers and followed in the footsteps of their Sikh forefathers to battle perceived injustices perpetrated against them.

Drawing on the literature on moral panics and folk devils, as well as the theorizing on hegemonic masculinities and crime, this analysis provides some preliminary insights on how Johal's legacy has been constructed. Through the narratives of 34 interview subjects who are 'authority' figures in the governance of gangs, this paper explores what these dueling legacies are, and their broader significance and relationships. Indeed, this paper asks the question: how has Bindy Johal as a social figure been imagined by authorities? I argue that Bindy Johal has been imagined as both a contemporary folk devil, corrupting a generation of vulnerable boys to join gangs, as well as a heroic figure who successfully achieved a form of manhood typically blocked to Punjabi young boys and men. Nevertheless, the overall effect of these contradictory narratives is the overshadowing of racism, class oppression, and the broader social context, and the region's history of religious extremist movements that might be the product of a local geographic condition that is unique to that area of Canada.

\section{The Story of Bindy Johal}

Understanding these competing narratives on Johal's legacy requires a brief biography on the man often characterized as a "mythic figure". Born on 14 January 1971, Bhupinder "Bindy" Singh Johal, Johal immigrated to Canada as a young boy from Punjab, India, although the exact city Johal was born is hard to locate. Raised by a single-working class mother, Johal was viewed as a problem child and performed poorly in school, as indicated by numerous behavioral and learning challenges he experienced in adolescence. Bindy was first introduced to gangs during a stint in prison for assaulting his high school vice principal. Upon his release, Johal would go on to work for the notorious Dosanjh brothers, predominate South Asian gangsters in the late 80s and early 90s. During this time, Johal became a major player in Metro Vancouver's gang scene, developing a muscular physique, a particular style of dress and clothing, and numerous sexual exploits with countless women, as close associate Diljit describes.

After a falling out, a bloody turf war emerged that resulted in the deaths of the Dosanjh brothers, of which Johal and several of his associates were criminally charged. Nevertheless, Johal and his co-defendants were acquitted of the murders in 1995. The case took a shocking turn, however, when a juror, Gillian Guest, was subsequently charged and convicted of obstruction of justice stemming from a sexual relationship she had with one of Johal's co-accused, Peter Gill, which likely resulted in the acquittals. Guest was given an 18-month prison sentence, but only served 12 weeks, garnering much media attention. The end of the trial nevertheless cemented Johal's reputation as untouchable, and the face of the "Punjabi gang problem". At its peak, Johal's criminal enterprise earned CAD 4 million annually from an assortment of illicit activities, including drug distribution, auto thefts, and even extortion and a murder for hire operation known as the Elite (Pearce 2009).

Johal's fortunes changed on 20th December 1998, when he was shot and killed while on the dance floor of a busy Vancouver nightclub. With many suspects who had a vendetta against Johal, it was one of his closest associates, Bal Buttar, who confessed to the killing years later. The salacious story of Bindy Johal captivated a generation of disenfranchised young Punjabi boys nearly two decades since his death, becoming a part of British Columbia's local cultural zeitgeist, and influencing how his legend has been shaped, however polarizing that legacy has become.

\section{Materials and Methods}

The arguments made in this analysis are derived from in-depth, in-person, and over-the-telephone interviews conducted with 34 individuals from August 2016 to January 2017, with some professional expertise on the phenomenon of Punjabi gang involvement across several municipalities in Lower Mainland British Columbia, including Vancouver, Surrey, Delta, Richmond, and Abbotsford. These 
individuals include representatives from community agencies who do some type of gang advocacy or support work. The category of work includes frontline workers, counsellors, activists, and even a number of former gang members who are involved in anti-gang programming. Additionally, police officers, both involved in gang enforcement and those who may volunteer their off-duty time to work with at-risk youth, are also included as viable research participants. Finally, the inclusion of school officials, such as principals, vice-principals, counsellors, teachers, and district level-employees, is also deemed necessary, as they interact directly with youth in high-risk communities, and often refer vulnerable youth to gang programming.

Purposive and snowballing sampling schemes were used to gain access to suitable research participants. This combination of sampling techniques is deemed necessary, given the ontological nature of this study, and allows for the selection of suitable research participants, based on their ability to provide valuable insights on Punjabi gang offending. With permission, interviews were tape-recorded and meticulously transcribed. The analytical technical of open-coding was utilized so that key concepts, categories, and properties could be derived from the data, a technique outlined by Glaser and Strauss (1967). Given the qualitative nature of this inquiry, a process of member-checking was used when deemed necessary. This involves a researcher seeking clarification on their interpretations and conclusions by research participants (Creswell and Miller 2000). This step ensures the researcher accurately captures the narratives of research participants, which can be challenging in ethnographic research. Finally, this study received ethical clearance from the University of Waterloo's Office of Research Ethics. To ensure the anonymity of interview subjects, culturally appropriate pseudonyms are used to conceal their identity.

\section{Literature Review}

\subsection{Contemporary Moral Panics and the Construction of a Folk Devil or Hero}

Stanley Cohen laid the foundation for much of the theorizing on moral panics and folk devils, defining these concepts as occurring when "a condition, episode, person or group of persons emerges to become defined as a threat to societal values and interests" (Cohen 2011, p. 1). Goode and Ben-Yehuda (1994) expand on Cohen's analysis of moral panics by articulating a set of criteria of which they are measured, including: concern, hostility, consensus, disproportionality, and volatility. When certain moral panics arise, like the fallout from a high-profile crime or series of crimes, folk devils attached to them are viewed as an existential threat to societal morality, and subject to strict social control (Goode and Ben-Yehuda 1994). Thus, folk devils represent evil personified, induce anxiety among law-abiding citizens, and often are the target of some negative reaction, as they provide a face to the moral panic that is currently in fashion. Gang members, gang leaders, and gangs in general have also undergone extensive analysis by moral panic scholars (Zatz 1987; St. Cyr 2003; McCorkle and Miethe 1998) as they embody key elements of the folk devil.

Examining the underlying motivation behind moral panics, Hall et al. (1978) look at muggings in 1960s and 1970s Britain, suggesting that moral entrepreneurs, such as the police and political figures, likely manufactured or exaggerated the dangers associated with this crime. This panic was initiated to divert the public's attention away from the economic anxiety people were experiencing as the result of the recession, and direct it towards British Black youth, who were identified as the folk devils associated with muggings (Hall et al. 1978). Therefore, moral panics may often work to conceal a far greater crisis that is much harder for policy makers, law enforcement, and other authority figures to address. This line of reasoning is similar to Rene Girard's theory of mimetic rivalry and scapegoating, which assumes people subconsciously imitate others both out of admiration, as well as a primitive urge to compete against those very same people they mimic. This leads to rivalry and potential conflict, with those on the outside looking for a scapegoat to blame, punish, and cast out of a community (Girard 1996). 
Given the changing nature of society, moral panic analysis has undergone several significant modifications in order to update it for modern times. For instance, some challenge Cohen (2011) original assertation as to the existence of universally agreed upon moral boundaries, which he suggests are often threatened and give rise to moral panics in the first place. Particularly, Hier (2008) argues that contemporary moral panics are far from universal, with Garland (2008) highlighting counter-reactions that develop to challenge the validity of claims made by alarmists. In an update to his text, Cohen (2011) responds to such criticisms by introducing the concept of a "generalized moral stance" to highlight a moral panic that is more predictable and born from a seamless web of social anxieties that exists in society. In this sense, through the generalized moral stance, the theorizing on moral panics aligns with the literature on governance and the risk society. Specifically, such panics develop from general anxieties individuals have become hypersensitive to by living in a perceived hazardous society, one where gangs and violent crime are viewed as common features (Ungar 2001).

While theorizing on the folk devil is plentiful, the concept of the 'folk hero' has not received as much attention among moral panic scholars. Flinders and Wood (2015) try to remedy this deficiency by understanding the reaction people have to heroic figures, and the euphoria and 'crowd joy' they can produce, which stands in stark contrast to the anxiety and indignation folk devils generate. However, under contemporary moral panics, where counter-claim makers sympathetic to folk devils emerge, theoretical analysis should be cognizant of the morally ambiguous gray area that exists, producing a condition where one person's folk devil may be another's hero, something not captured in Flinders and Wood (2015) analysis. Related to the aims of this paper in particular, the elevation of certain criminals from villains to heroes is important. Kooistra (1989) examines such a transition, such as the admiration some have towards certain criminals like killers or thieves when their acts are perceived as a response to some symbolic resistance to a wrong that has occurred. This archetypal "Robin Hood" figure is affixed cultural group values, like loyalty or courage, and who's criminal behavior is attributed to a social injustice that has precipitated and motivated their crimes (Duncan 1991).

\subsection{Masculinities and Crime: Racialized Men and Offending}

"Manliness" is a socially desirable trait that some individuals might look for in a hero. Indeed, the theorizing on masculinities and crime sheds light on how a gangster may be viewed as a hero for some. Connell (2005) concept of "hegemonic masculinity" has been particularly useful in understanding men's monopoly over physical violence, which is not only directed against women but other men as well. Masculinity falls under a spectrum where at one end is the 'hegemonic ideal', a dominating, oppressive representation of manhood that ensures the institutional supremacy of men who meet this standard (Connell 2005). Violence then is a tool used by some men to preserve their hegemonic status and superiority, as a counter-measure when they feel wronged, or to reclaim a sense of justice owed (Chodorow 2002).

Men who do not meet this standard fall at the other end of the spectrum and possess a subordinate masculinity, yet, despite their station, all men are required to position themselves in relation to the hegemonic masculine ideal (Connell and Messerschmidt 2005). As Morrell (1998) explains: "the concept of hegemonic masculinity (which) provides a way of explaining that though a number of masculinities coexist, a particular version of masculinity holds sway, bestowing power and privilege on men who espouse it and claim it as their own" (p. 608).

Certain racialized and disenfranchised men are considered to have subordinate masculinities, including working-class males, on account of failing to reach socially desirable economic goals based on their lived realities (Hooks 1995). Additionally, under the stress of structural powerlessness, some men resort to gangs as an alternative way of performing masculinity, making hyper-masculinity through violence an antidote to poor self-esteem (Messerschmidt 1997). Thus, Vigil (2007) suggests that gangs are an expression of marginalized masculinity. Adding to this, Rios (2011) examines the gang behavior of urban racialized men, suggesting that gang symbols, dress, and language, as well as hypermasculine behavior, are ways to reclaim lost status and stake a claim on the masculine hierarchy. Similarly, 
Gutmann (1996) looks at cultural machismo among Latino gang members as a form of reworking masculinity for marginalized men, themes this study examines through Johal.

Punjabi men have not received as much attention among the masculinity and crime literature. More broadly, South Asian masculinity is regulated under subordinate status, as it falls short of meeting the hegemonic standard (Finch-Boyer 2014). However, the performance of masculinity for some South Asian men requires the endorsement of machismo or traditionally masculine beliefs in order to protect family, and preserve the honor and purity of women or caste identity (Gilmore 1990; Malhotra 2002; Dube 2001; Yim and Mahalingam 2006). Frost (2010) provides one of the few analyses on South Asian gang involvement in British Columbia, linking it a group of males classified as "Surrey Jacks". A Surrey Jack is a subculture of Punjabi boys with a set of expectations on the performance of masculinity, which ultimately resembles a counter-protest to the dominant hegemonic standard (Frost 2010). According to Frost (2010), the Surrey Jack stands in contrast to the "Brown boy", a category of South Asian males who more closely align their masculinity with the standards established by their white peers. Surrey Jacks, on the other hand, are more willing to use violence and aggression at slight provocation, and are blamed for the perceived gang problem. Frost (2010) defines "the Brown boy" in relation to the "Surrey Jack":

"These boys' conceptions of their ethno-racial identities are bound up with their understandings of masculinity, how brown has evolved as an alternative way of "doing male" which not only contests a white hegemonic masculinity but confronts versions of Punjabi masculinity embodied by their fathers as well as the media's representation of the typical Indo-Canadian man or "Surrey Jack" which has emerged in Surrey as a form of subordinate protest masculinity". (p. 213)

A figure like Bindy Johal may be celebrated by "Surrey Jacks", as well as other young Punjabi boys who have had to navigate and perform a protestive form of masculinity.

Punjabi-Jat ethical codes centered on male Izzat (honor), a cultural moral principle that is associated with a man's reputation, and the respect and dignity he is able to covey (Das 1976). A man's izzat also dictates the level of power, influence, and authority he commands (Das 1976). Nicola Mooney (2013) suggests that hypermasculinity is a reactionary response to the construction of South Asian men as feminine by the British. An alternative means to obtain izzat for young Punjabi boys then, is the hypermasculine performance of masculinity in order to achieve power, respect, and reputation. Izzat is also relational. For the Sikh-Punjabi male, the women in his life (i.e., daughters, sisters, wives) are associated with his izzat, which is strengthened in his ability to protect and guard them (Mooney 2010). Female relatives must also uphold a man's izzat, by regulating their behavior and not bringing sharam (shame) to the family.

\section{Results}

\section{1. "Never Use His Name"-The Construction of the Folk Devil}

Pseudonyms for interview sources are used in the following sections to reveal the stories being told of Bindy Johal. Most dominant among the narratives is that Bindy Johal represents something insidious to the Greater Vancouver Area, someone who the community can collectively blame for the continuing gang violence. Not only has Johal given birth to the modern-day Punjabi gangster, but he personifies all the negative attributes attached to the risky Punjabi male. Retired gang enforcement officer John explains the significance of early Punjabi gangsters, like Johal, in transforming the gang climate in BC:

In the day [gangs] were very organized and there was a sense of, they kind of all got along, it was good for business not to fight and war and they were making lots of money. But when you get people like Bindy Johal and Raj Cheema and some of these guys come into the game, 
they're just complete killers. There was no honor among thieves as there was. It just turned into murder and mayhem. (John, interview, 27 September 2016)

Officers like John stood on the frontlines of early gang warfare between Indo-Canadian young men, witnessing the rise of gang members that he believed were far less honorable and more sinister than the gangs that preceded them. The honor system this new breed of gangsters observed contrasted with the hegemonic honor code of white men, their forefathers, or their peers-the Brown Boys. This more nefarious breed of gangster, of which Johal takes center stage, becomes the focus of a moral crusade launched by moral entrepreneurs like Officer John. Officer John believes Johal still has the ability to seduce young Punjabi males to gangs to this date. The framing of a threat as "new" or different, and hence more dangerous by agents of social control is a defining feature of moral panics on crime, especially when they are transmitted by law enforcement.

Johal's folk devil status is further cemented through the apprehension some have in even saying his name, as naming the devil may legitimatize his appeal among Punjabi youth. High school teacher Simran makes a conscious effort to not say Johal's name in front of her students:

I also think that a lot of gang activity is glamorized online. Like I know our kids, like we're trying not to use the name Bindy Johal in our area. Every grade 8 kid is talking about him as he is some hero who defied the police and got killed and his interviews are online and people are looking it up and these grade 6, 7 kids are always searching them up and bringing him up. So, one thing I decided is never ever to use his name or react to his name. (Simran, interview, 1 December 2016)

For Simran, the media has glamorized Johal as a hero providing the foundation for his admiration by youth. Simran's reluctance to say his name or react to it if mentioned is indictive of the anxiety a folk devil can produce, since much of the gang violence associated to Punjabi boys is problematized as the outcome of youth emulating Johal, and their keen interest in his life. Yet, not all display the level of apprehension in naming Johal as Simran does, particularly community activist Harjit:

Bindy Johal, his name keeps coming up, and rightfully so, because a lot of youth that contact me are still aware of him. Like, I'll go to high schools, twenty years after the fucking guy has been dead, and they're like: Hey, Bindy Johal, he's the man. He's the man. He put us on the map. Bro, he didn't put you on the map, he put you on the pavement. You're going to live a lifestyle that's going to get you shot or killed. (Harjit, interview, 29 August 2016)

Harjit believes that identifying the "devil" is a necessary step in order to delegitimatize his legacy, and to weaken the appeal he has to his admirers. The notion that Johal's lifestyle ultimately results in an untimely death is stressed by others in the community like Officer Ranjit who works to deconstruct his legacy and accentuate the ultimate cost of his villainy:

We went through that initial iteration of these groups going back to the Dhosanj's and Bindy's and they became like cult like figures to these people. Like a lot of these kids want to emulate them and think that: "Oh yeah it's the girls. It's the power, it's the money." And then we're always hammering the other aspect: "Where are they? They're all dead before they're 25. So, if that's the lifestyle you choose, you know, it's great for a little bit to think your king, but where are you going to end up long term?" (Harjit, interview, 3 October 2016)

Ranjit appeals to the rationality of young Punjabi boys by highlighting that drive to make money, and to gain power, respect and women, ultimately comes at a fatal cost. As the reaction to a folk devil is of utmost importance to moral panic analyses, Johal's violent murder is often used to steer youth away from gangs. Specifically, the Truth About Gangs initiative has been used in local schools as a gang prevention technique, which involves police presenting pictures of a dead Johal lying on a morgue table with bullet wounds and tubes connected to his body to school-aged children (Bailey 2008). Despite the 
harsh reactions by teachers, these pictures of Johal are meant to shock and scare young Punjabi boys away from gangs by illuminating the consequences of gang involvement, and are a counter-measure to dismantle his glamorized appeal on youth.

In addition, Johal becomes a more fearful figure when his deviance is amplified, inflaming an already heightened moral panic. Deviance amplification by respondents occurs in two ways: (I) by connecting Johal's influence to specific family members who could have fallen prey to his influence; and (II) by associating him with some of the other 'evils' in the community, namely, the extremist Sikh Khalistani movement. The separatist movement, which resulted in the several acts of violence across the world, gained increase popularity in British Columbia, coinciding with the rise of Punjabi gangsterism. First, some respondents point to the degree of influence Johal exerts by drawing attention to how certain family members escaped his grasp. Teacher Simran discusses her husband's prior history with Johal:

Bindy Johal went to the same high school my husband graduated from. He tried to recruit my husband in grade 12 and that's a story he has shared with me ... back in the 80 s and my husband went to the same school and he invited him, my husband, a lot of times to come to his house and [say]: "I'm going to introduce to these people and you can make money." And my husband didn't make those choices. He didn't really go. (Simran, interview, 1 December 2016)

For Simran, her husband was able to reject Johal's dangerous proposition and make the "right" choices. Had he followed in Johal's footsteps however, Simran believes that her husband's life, and by extension hers, likely could have unfolded quite differently. Simran frames the struggle young Punjabi men in that region faced at the time, which is their ability to withstand Johal's influence. Anita, who operates a community safety program, similarly personalizes the danger Johal posed to a family member:

It's really interesting from what I've seen. My husband's family, three boys grew up. They're all professionals ... yeah, a South Asian family. Three boys grew up. They're all professionals. They all went to University and my husband played football with Bindy Johal. Bindy's one of the most notorious South Asian gangsters and my husband was on the force and arrested Bindy and the Dhosanj brothers. Was on the Swat team for [name of police service omitted]. Was involved heavily with the gangs and it was really interesting when Bindy Johal was taken out, these police officers were relieved because he was killing a lot of people. (Anita, interview, 17 August 2016)

Anita frames her husband as a heroic figure, the model to which Punjabi boys should aspire, a position that is diametrically opposed to Johal's gangsterism. Heroes like her officer-husband played an important part in vanquishing the devil, and even felt some level of comfort with Johal's murder, because it brought an end to the horror and violence he inflicted on the community. Both Simran and Anita use personal examples to illustrate the scope of Johal's power, as they have first-hand knowledge of the threat Johal posed through the lived experiences of loved ones and the proximity they had to the notorious gangster.

Finally, Johal's deviance is amplified by being connected to some of society's other social ills. Activist Harjit draws on Johal's connection to the Sikh extremist movement:

You might not know this but a lot of the original gangsters, like Bindy Johal and these guys, their fathers were involved at a certain level, or supporters of things like Babar Khalsa, the Khalistani movement ... They were all for the 1984 retaliation attacks and stuff like that. We're talking about a lot of the original gangsters, the Dhosanj brothers were part of the United Sikh Federation or sorry the Sikh Youth Federation. So, these guys have backgrounds in separatist kind of mentalities, or their families at least did, or they're involved at a cultural or even a religious level. (Harjit, interview, 3 October 2016) 
Johal is a figure that is more frightening and dangerous when his deviance is broadened in such a manner. The Khalistani movement has a long history in Canada, particularly Western Canada, developing a moral panic over religious extremism, which intensified following the bombing of Air India Flight 182. This terrorist attack was alleged to have been planned and carried out in the Vancouver area by those associated with the Khalistani movement. By connecting Johal's father (among other gangsters) to the Sikh separatist movement, Johal becomes not only responsible for the gang violence plaguing the community, but is now somehow indirectly responsible for the community's panic on dangerous religious and political ideology. In other words, there is no better way of solidifying Johal's status as a folk devil than by connecting him to another source of a community's anxiety: Sikh extremist movements.

However, not much is known about Johal's father and whether he was indeed involved in the Khalistani movement. During the 1980s, the Babbar Khalsa drew much fundraising support in the Vancouver area from the local Sikh community (Purewal 2012). Considering Johal formidable years coincide with rise of the Khalistani movement, and that the Vancouver was the political and social epicenter of the cause, Johal's father may have had these connections to the Babbar Khalsa and other fundamentalist groups. However, the lack of publicly available information about his father has left room for Johal's legacy to grow. In this sense, the elder Johal's alleged activities have been absorbed into his son's legacy, cementing Bindy Johal's status as a mythic figure. Whether Johal's father was actually involved in the Khalistani movement is less important, but rather, the belief that he was a part of the Sikh separatist movement is an integral part of the myth building process as it works to further demonize the Johal name. This provides a connection to the rise of the Khalistani movement with that of gangsterism in the region.

These narratives paint a legacy of Bindy Johal that is steeped in gang violence, one that has been glamorized in the media and admired and emulated by a generation of Punjabi boys. Yet, this take on the Johal legacy is not the only one that exists; a counter-narrative exists that views Johal in a more sympathetic, and perhaps even heroic light.

\section{2. "A Fucking Legend"-The Construction of a Local Hero}

Johal's status as a folk devil overshadows a different legacy that has emerged in the region, one that views him as a hero. As mentioned above, a source of fear among some in the community is that youth admire Johal, which some have referred to as the "Bindy Johal effect". Former gang unit officer John describes the effect Johal has on young boys:

I was a police officer in South East Vancouver, which is the South Slope, it's predominately a South East Asian community down there. So, for five years in uniform I worked in that area. I got to know a lot of the young kids I met as teenagers, evolved into unfortunately, that lifestyle. They kind of followed in the footsteps of Bindy. Bindy was actually famous, somewhat of a role model for a lot of the young South Asian kids unfortunately. They didn't go after positive role models. They saw him in the news every night and they saw him as some type of cult superstar or something, I don't know. (John, interview, 27 September 2016)

Officer John draws on Johal's celebrity status, and like their favorite athletes, movie, or pop stars, his ability to have youth emulate him. However, as indicated at the end of his comments, Officer John does not know the source of Johal's superstar status, or why youth aspire to follow in his footsteps. Fellow police officer, Scott, provides a few more insights as to why Johal's entry into the gang scene in the early 1990s is significant, and why young Punjabi men were keen to imitate him:

We see this almost mythical evil figure in Bindy Johal. And Bindy Johal is engaged in the drug trafficking field and he's up against the Dhosanj brothers and there's this video clip that I have of Bindy challenging the Dhosanj brothers on the six o'clock news and the Dhosanj brothers getting back at him and then there's violence. So, what happens within the 
Indo-Canadian community, and this is still to the day to a certain extent, that Johal's got this sort of mythical following among young people, because he's this guy who basically he's not playing the typical if you will, traditional quiet, studious, law abiding Indo-Canadian young guy. He's breaking the mold and he's going to be the bad ass gangster. And so, kids really look at that and the glamorization and he got away. (Scott, interview, 29 September 2016)

Officer Scott makes an important point around Punjabi masculinity and how Johal's cult status was developed. As a local cultural icon, Johal stood against the typical masculine expectation of the South Asian man as framed by dominant White Anglo-Saxon standards. In the performance of masculinity, South Asian men are expected to be quiet and studious, an image that ultimately serves to subordinate their masculinity, and a baseline for which Punjabi men are evaluated and compared. Johal shattered this stereotypical expectation of the submissive Indian man by adopting a hyper-masculine personality through the gangster life. Consequently, Punjabi men were now constituted as "risky" or "dangerous", a narrative that some may have embraced as a badge of honor as it is more reaffirming of their masculinity. Status-decline might be a common experience for many Punjabi-Jat males, particularly young boys dealing with racism and emasculation in Canada. Further, traditional means to preserve izzat, like land ownership, are not readily available in host countries. As Mooney (2013) notes, hypermasculinity may be one form of achieving izzat, making gang involvement for some Punjabi males an alternative method to gain power, status, and an influence for boys who cannot achieve it the way their forefathers were able to.

Having shared the same experiences as Johal, former gang leader and Johal associate Diljit understands the motivations of young Punjabi men adopting gangsterism:

“So Bindy comes along and he's fucking ripped with fucking muscles. He's got 40 fucking pounds of gold around his fucking neck. He's just shot three fucking people and he's laughing about it on fucking TV ... It's an emasculated male driving around in a Corvette .... Forty chicks lining up at a bar to suck his [redacted]. "Hey take a number. Take a number, girls". Guy turns into a fucking legend. In terms of race, it's really interesting in terms of race relations how these things ... how does this work? And it fucking made a difference. Fucking white folks stopped fucking around with fucking East Indians after that. They we're like "okay maybe I'll just keep my mouth shut next time I'm thinking of calling you a Hindoo". When we sit down and think about race relations in this country and our community, shit we look at people like fucking Bindy and say "hey. Did he do something for our community?" Did he? Like moralism aside, put the ethical, moral shit, let's just deal with power relations. And so, when you look at South Asian young men today, this guy becomes fucking icon. He becomes a fucking god in the imagination of the emasculated South Asian male. All of a sudden, they're like "oh right. We can fucking do this."" (Diljit, interview, 15 August 2016)

While likely exaggerating certain aspects of Johal's life to get his point across, Diljit highlights two salient issues that need to be unpacked. First, a significant problem associated with the masculinity of racialized men, particularly South Asian and Asian men, is the perception that they are less masculine than White men, who hold the hegemonic standard (Shek 2007). Therefore, a consequence of a being hobbled with a subordinate masculinity is that South Asian men may be considered less sexually desirable (Balaji 2012). Diljit suggests Johal was able to overcome this subordinate status and stake a claim on the hegemonic masculine standard through a hyper-masculine personality, and as a consequence, engaging in hyper-sexual activity. While crude in his assessment, Diljit points to a transformation of both body and attitude that made Johal more sexually appealing as evident by the number of sexual partners he was able to attract. As folk devils are tied to a particular dress and style, Johal's muscular physique, gold jewelry, and overt sexuality became symbols to generations of young Punjabi boys as to how masculinity should be performed. 
Diljit makes another important statement related to the experiences of racism young working-class Punjabi males were subjected to. According to Diljit, being called a "Hindoo", a regional derogatory term, along with bullying and physical violence was not uncommon for boys like him and Johal growing up in predominately White, working-class neighborhoods. Indeed, the term Hindoo has a long history in North America, and was used to emasculate mostly Sikh and Pakistani migrants in the 19th and 20th centuries (Thangaraj 2012). As Thangaraj (2012) notes, discriminatory laws forced South Asian men to form bachelor communities, as "Hindoos" were viewed as perverse and subjects unsuited for full citizenship in their host countries. At its core, the slur "Hindoo" continued the tradition of demasculinizing South Asian men like Johal or Diljit, requiring them to respond through violence and gangs. Thus, similar to Frost (2010) analysis, for Bindy and young Punjabi males who followed, masculinity became a form of counter-protest to the dominant hegemonic standard that they could not meet due to their working-class, minority backgrounds, and the domineering racism of the time.

Feelings of social exclusion are often associated with racism. Anju, who works with several community groups and projects on gang violence, makes an important argument that ties some of Diljit's arguments together:

So, I think there's a big history of that and Bindy Johal, you know, was often excluded in clubs, while White people were allowed in. And so, he felt he needed, or others also of his caliber needed the bling, bling to gain more recognition. So, there is the racism that is manifested through bullying. There is the lack of recognition because of race, the exclusion and then the need to have this bling, bling compensates for that inferiority that's socially constructed around South Asian. (Anju, interview, 29 September 2016)

According to Anju, the gold and jewelry, which became symbols for Johal and his gangster lifestyle, were the result of this performance of a counter-protest masculinity. In order to overcome feelings of inferiority that were brought on by racism and social rejection and achieve some form of recognition, Johal and his followers adopted a distinct new subculture for the disenfranchised Punjabi man that provided them entry to spaces, such as nightclubs, that they were typically excluded from.

It is clear that the source of Johal's admiration lies in his ability to shatter stereotypes of the Punjabi male and achieve some level of masculinity along the hegemonic standard that typically eludes South Asian men. In other words, Johal is perceived to have fought a system that is unjust and unfair to brown boys like him. High school teacher Lena discusses the appeal Johal has with her students today:

They want to be known as somebody. They want to be seen as someone that is important right? ... So that sense of racism, they want to escape that and just be known, and wow Bindy Johal is important. And I bring out the name Bindy Johal is one of these lions, right? Legends in the 80 s that kids know. They all know that person and they might not like what he did but they point to the fact that everybody knows his name. That he's still considered, right? He put the South Asian population on the map in a different way and I think some of the things Bindy Johal said was about racism, it was about this idea of taking back the power. I completely disagree. I usually tear apart that argument in class but it's interesting to note that that does matter to some of our students. That they do want to be known as something other than just what the larger society sees them as.

From Lena's account, Johal's heroic status among Punjabi youth parallels the lived experiences of African Americans and expressed through gangster rap where "taking back the power" by standing up to racially unjust institutions like the police were common cultural messages transmitted by disenfranchised youth (Lusane 1993). Consequently, in a separate point, Lena mentions the negative perception the city of Surrey typically evokes and how her Punjabi students express being discriminated against as a consequence of the community they call home. While his criminality is not lost on these youth, Johal is a central figure in the local cultural zeitgeist, and glamorized in the media, according to the stakeholder narratives captured in this study for similarly taking back the power against a system that has left Punjabi boys feel powerless, isolation, and discriminated against in their own communities. 


\section{Discussion}

\subsection{Overlooking a Far Greater Crisis: Johal Represents the Problems of South Asian Masculinity}

Johal's legacy is hard to situate within a singular narrative, because it does not clearly fall under the hero or villain category. On the one hand, Johal is perceived as some contemporary folk devil, and his legacy remains harmful for its ability to seduce a new generation of Punjabi boys into gangs. This narrative stands in stark contrast to a more sympathetic view of Johal by highlighting the racial barriers he was able to overcome. Through an exaggerated performance of masculinity, one characterized by displays of aggression and hypersexuality, Johal became an icon for the newly emancipated South Asian male, free them from their subordinated position on the hegemonic masculine hierarchy.

The ambiguous gray area that the legend of Bindy Johal appears to fall under is easier to understand within the context of deviance admiration and the idolization of criminals. For instance, Johal's cult hero status stems from his symbolic resistance to the perceived racial injustices that have plagued Punjabi young men in that region. Duncan (1991) suggests that criminals become admired when their criminal acts are seen as a response to a prior injustice or wrong that has befallen them, which, in Johal's case, would be his many gang-related activities that are attributed to bullying and racism. This is a point Anju makes:

Well it starts off with the bullying. Many of the South Asians gangs started because of racism. That they were beaten up, young Sikh boys that had their patkas [Sikh turban for young males] ripped off, a 13-year-old would be kicked by a 17-year-old. Total humiliation and so Sikhs wanted to, or South Asians primarily Sikhs, wanted to actually defend themselves and they got together. Initially they were gangs to protect themselves and then you get into illegal drugs. So, I think there's a big history of that and Bindy Johal.

Racism and bullying against South Asians is clearly framed as the injustice and necessary precursor to gang involvement, which were initially formed out of a need for protection and a line of defense against physical violence. Drug offenses and other material benefits for gang involvement are deemed as secondary motivations for gang-involvement, and came after as an added bonus, according to Anju. Anju's account illustrates how some may admire Johal when his actions are born out of an injustice, making it easier to romanticize him and rationalize his actions for the "greater good" of a racialized community. Yet, most are not willing to reconcile the impartible harm he has caused and the violence he has inflicted and continues to inflict after his death. For them, Johal remains a folk devil to pin gang violence on, which appears to be the more dominant of the narratives coming from that region, as it is the most supported by official agents of social control.

This provokes a fundamental question: what is the overall consequence of these competing narratives on his legacy? While both images of Johal's legacy appear contradictory, they do share an important relationship, a connection that is best understood within the context of how crises are policed. In the seminal work by Hall et al. (1978), a moral panic over muggings in 1960s and 1970s Britain was manufactured by official agents, like the police, to divert the attention of the public from the poor economic conditions brought on by the recession. As a consequence, young Black youths were framed as a threat, and the folk devils associated with the "wave of muggings", overshadowing the more pervasive and significant economic crisis of the time.

Under a more nuanced interpretation of Hall et al. (1978), it is apparent that Bindy Johal has also been similarly imagined as a threat to the moral functioning of the community and the source of the community's gang problem. Yet, those who frame Johal as a folk devil might be doing so less purposefully, as Hall et al. (1978) suggest happens when crises develop. In other words, the moral panic over Johal's influence over young Punjabi men might not be a manufactured crisis, but one that has organically developed but still produces the same effect. Specifically, this crisis misplaces blame for gang involvement on an individual who is easy to blame, rather than addressing a far greater crisis surrounding Punjabi masculinity. Thus, in this case, a crisis over Punjabi masculinity for working-class 
boys serves as the overarching problem that goes unnoticed by central figures in the discourses on gang violence that have emerged in that region. Introspection as to why Johal may have turned to gangs is largely overshadowed by the perceived harm he is believed to have caused and continues to inflict in British Columbia.

Girard's framework on mimetic rivalry and scapegoating can also be used to understand the demonization of Johal in the region. The intra-racial violence among Punjabi young men is indictive of the mimetic rivalry Girard articulates. Essentially, competing conceptions of izzat (honor) and masculinity breeds the violence being witnessed in Western Canada, which at its core is centered on the belief that young men are imitating Bindy Johal. This makes him an easy scapegoat to posthumously blame gang violence on, while downplaying or ignoring how as a social figure, Johal animates notions of masculinity, class, and izzat among disenfranchised Punjabi boys in the region.

\subsection{Sikh Warriors: From Terrorism to Gangsterism and Its Long History of British Columbia}

No analysis on Johal would be complete without understanding the local history of the region, and the development of panics that have impacted the sizable Sikh community in British Columbia. A significant number of Sikhs have settled in British Columbia, where they have continued to follow and practice their religion. Indeed, the free practice of one's religion is a fundamental belief of Sikhism, of which Sikhs are willing to protect if threatened. Indeed, Sikhism was founded in the 16th century Northern India as a distinct religion from majority Hindu and Muslim population. While living relatively peacefully, Sikh warriors emerged in the 17th century to fight against the reigning Mughal Empire and their often-violent campaigns of forced conversions to Islam. This signified the transformation of Sikhs from a passive and relatively peaceful religion to that of the, the religious warrior or solider (Razavy 2006). The image of the warrior Sikh became an important symbol, and has been appropriated by some when perceived cultural and religious threats arise. In fact, the Lower Mainland of British Columbia is unique, in that the very image of the warrior Sikh has become a part of that region's history and the source of two moral panics, one over terrorism and the other over gangs.

The fear of religious extremism centres on the Khalistani movement, a collective of individuals advocating for a separate Sikh state in Northern Punjab, India. The separatist movement caused significant political violence and turmoil in India including three important watershed moments: (1) the storming of the Harmandir Sahib, the Golden Temple and the Sikh's holiest site, by the Indian army; (2) the revenge assassination of India's Prime Minster, Indira Gandhi, in 1984 by her Sikh bodyguard; and (3) the retaliatory violence against Sikhs by Hindu nationalists upset over Gandhi's killing. Noteworthy is that British Columbia has the largest Sikh population outside of India, where they tend to form dense ethnic enclaves in cities like Surrey, Richmond, Delta, and Abbotsford (Todd 2012).

While drawing on support across the globe, including in Ontario, the UK and the United States, British Columbia appears to have been the epicenter of the West's engagement with the pro-separatist Khalistani movement, becoming a part of the local culture and Sikh diaspora. With political violence in India against their people, coupled with a profound sense of isolation and a feeling of not belonging to Canada, the movement may have offered disenfranchised Khalistanis, who are generally more traditionally dressed turbaned-Sikhs, a sense of community and purpose (Chakraborty 2015).

Activist Harjit notes the regions connection to the Khalistani movement:

The Khalistani movement is still very prevalent in the mentality around here. In a lot of the Gurdwaras around here, they worship guys like Bhindranwale. That whole Khalistani movement is big here, where they want a separatist mentality from India. They want their own Sikh Khalistan right. (Harjit, interview, 29 August 2016)

As a result, the Khalistani movement flourished in British Columbia and local figures emerged to contribute to the fight for an independent Sikh state in India. Consequently, Gurdwaras (Sikh temples) in Vancouver, Surrey, West Minister and Abbotsford were taken over by pro-separatist groups as sources of fundraising (Razavy 2006). This culminated in the bombing of Air India Flight 182 in 1985, 
killing all 329 passengers, the majority of which were Indo-Canadians. This attack was believed to be planned and carried out by members of the Babbar Khalsa, a leading Khalistani group in British Columbia as a message to India's government (Singh and Singh 2008). Acts of violence in the name of a free-Khalistan are often celebrated, admired, or respected as warriors by supporters sympathetic to the cause (Dorn and Gucciardi 2017). Thus, those who carry out political violence are likely perceived as more modern-day soldiers fighting against threats to Sikh sovereignty akin to the religion's early leaders who fought against Islamic rule.

Although Sikhism encourages carrying on the warrior tradition, typically as soldiers, it does not support criminal gang membership (Dorn and Gucciardi 2017). Interestingly, despite this, the Sikh warrior or solider label has been appropriated by gangsters or those sympathetic to figures like Bindy Johal to frame their criminality. First, as Anju notes above, Punjabi youth initially joined gangs because of bullying, particularly turbaned Sikh boys who had their "patkas ripped off". Thus, in the face of threats to their religion by racist bullies, gangs were formed by people like Johal from a sense of solidarity, protection, and fighting against racial and religious bigotry. Former gangster Diljit explains the connection between gangs and the image of the Sikh warrior: "I think even for a lot of your young people, we're looking for something to fight. And you know, Sikhism, it's got a brave warrior tradition." (Diljit, interview, 15 August 2016) For Diljit, the warrior mentality that gang members like him developed stems from religious notions of the brave warrior fending off threats to individual liberty and cultural identity.

Officer Scott makes a related statement: "I think Sikhism talks about the Sikh as the warrior, right? And I think that many of the youth are misinterpreting the teachings of the temple, right? They're not hearing the full message of the guru, right?" (Scott, interview, 29 September 2016). Officer Scott attributes the gang involvement of young Punjabi men to a misguided interpretation of Sikh scripture and the purpose of warriorhood. Harjit expands a bit on Scott's statement:

I think the whole Khalistani, we're warriors, we come from a Sikh background. When words don't work, pick up swords, that kind of Guru Gobind Singh mentality. They carry that around. That might come from a religious standpoint or just their cultural upbringing, but I don't think it's a huge factor. (Harjit, interview, 29 August 2016)

For Harjit, the warrior mentality plays some role in the gang involvement of Punjabi boys in the region, albeit acknowledging that it may not be as influential as other factors. Nevertheless, these narratives suggest that Sikh tradition and the image of the warrior/solider/sant has been especially potent in British Columbia and connected to the moral panics around gangs and terrorism. Johal, the warrior, was a symbolic figure who stood up to racial bullying Sikh's experienced, while those involved in the Khalistani movement are similarly admired by some for their fight against perceived injustices related to a lack of true homeland. A main issue of the Sikh diaspora is local integration and the loss of the Sikh identity and living on the outside of the homeland (Kalra et al. 2005). Considering the challenges posed by integration and identity loss, with the added experience of bullying and racism, disenfranchised Punjabi-Sikhs in Canada may attach themselves to figures that fight perceived injustices, whether that be a lack of true homeland or threats to their masculinity.

This produces a local cultural phenomenon where the image of the warrior is appropriated mostly by disenfranchised Sikh men, and they engage in behavior that is otherwise deemed deviant and criminal by society at large. In some ways, the principle of "fighting for the homeland" is adopted by the Punjabi gangster, who imagines the home/nation quite differently than the Separatist. For some second-generation youth born and raised in British Columbia, there may be a lack of connection to Punjab and Khalistan as the true Sikh homeland. Further, on account of racial discrimination and feelings of social exclusion from Western society, Canada may not truly feel like home either for those young men. This creates an interesting tension where competing conceptions of masculinity, honor, and finding a "home" play out in the form of gang violence and offending in British Columbia. 


\section{Conclusions}

Bindy Johal's life is a remarkable story with plot twists and salacious details more fitting of a Hollywood movie than real life. Johal reached a level of regional notoriety and fame that typically eludes working-class Punjabi boys, and is likely why his legacy resonates with some to this date. As a polarizing figure, Johal is viewed by some as a clear villain and corrupting force, while others may be more empathetic towards him and recognize why he may be a source of admiration among youth. On the surface, Bindy Johal acutely fulfills the 'folk devil' role, and can be easily blamed for the community's gang problem. Yet, any analysis must be cognizant on how such moral panics manifest themselves today, especially since there is no clear consensus on social problems. On one hand, alarmists believe Punjabi youth are being led down the same gang-ridden lifestyle as Johal, while others make counter-claims recognizing his appeal among boys who relate to his struggles. Additionally, as a contemporary moral panic, the fear over Johal's influence on youth is not generated by erratic and volatile bursts of panic that would require immediate action, but instead is a fear that remains a part of the community's conscious and general anxiety over gangs for a more sustained and prolonged period of time.

This analysis reveals several important details of the Bindy Johal story. On the one hand, Johal is deemed a corrupting force, influencing young Punjabi men to join gangs. This includes reluctance to name the devil, share stories of loved ones who may have fallen under his grasp, and amplify his deviance by connecting him to the Khalistani movement, despite a lack of evidence. Nevertheless, a counter-narrative has emerged that is more sympathetic to Johal, and understands his appeal. This outlook on Johal's legacy salvages some of "the good" he may have done for the Punjabi community. Specifically, Johal was able to break Western stereotypes and prevailing challenges faced by racialized, working-class boys and young men. This was achieved through hyper-masculinity and gang involvement.

These narratives point to a distinct regional story that has emerged in British Columbia, and is a part of the Sikh diaspora. Mainly, a fear centered on a particular warrior-type mentality young, Punjabi Sikh men are adopting, which fuels the community's anxieties over terrorism and gangs. Future research would benefit from a richer analysis of the Khalistani movement, and how it might connect to the issue of gangs. This would require broadening the scope of the study to include a more general look at moral panics involving the Sikh community in British Columbia.

Finally, as Hier (2008) suggests, a more substantive moral panic analysis must examine the responses or reactions elicited when such folk devils arise. During the course of this study, it has become apparent that counter-programming exists that aims to delegitimize Johal's appeal to youth. A Punjabi languages course and mentorship program operating in one BC school district, which serves to provide youth with positive Sikh role-models and mentor figures that stand in contrast to what Johal has to offer. These figures include current and historical Sikh-Canadians in the areas of the military, politics, sports, journalism, and the media. Future research may want to examine how the reaction to Johal has influenced the governing of others, particularly youth who are perceived to be susceptible to gangs, through an analysis of such programming.

Funding: This research received no external funding.

Conflicts of Interest: I declare no conflict of interest as author of this article.

\section{References}

Bailey, Ian. 2008. In Schools, Bloody Photos Deliver Anti-Gang Message. The Globe and Mail. July 2. Available online: https://www.theglobeandmail.com/news/national/in-schools-bloody-photos-deliver-antigang-message/article957861/ (accessed on 18 April 2019).

Balaji, Murali. 2012. Competing South Asian Mas(k)ulinities: Bollywood Icons Versus "Tech-N-Talk". In Communicating Marginalized Masculinities: Identity Politics in TV, Film, and New Media. Edited by Ronald L. Jackson II and Jamie E. Moshin. New York: Routledge, pp. 57-72. 
Chakraborty, Chandrima. 2015. Official Apology, Creative Remembrances, and Management of the Air India Tragedy. Studies in Canadian Literature 40: 111-30.

Chodorow, Nancy J. 2002. The Enemy Outside: Thoughts on the Psychodynamics of Extreme Violence with Special Attention to Men and Masculinity. In Masculinity Studies and Feminist Theory: New Directions. Edited by Judith Kegan Gardiner. New York: Columbia University Press, pp. 235-61.

Cohen, Stanley. 2011. Folk Devils and Moral Panics: The Creation of the Mods and Rockers, 4th ed. New York: Routledge Classics.

Connell, Raewyn. 2005. Masculinities. Berkeley: The University of California Press.

Connell, Raewyn, and James W. Messerschmidt. 2005. Hegemonic Masculinity: Rethinking the Concept. Gender $\mathcal{E}$ Society 19: 829-59.

Creswell, John W., and Dana L. Miller. 2000. Determining validity in qualitative inquiry. Theory into Practice 39: 124-30. [CrossRef]

Das, Veena. 1976. Masks and Faces: An Essay on Punjabi Kinship. Contributions to Indian Society 10: 1-30. [CrossRef]

Dorn, Walter, and Stephen Gucciardi. 2017. Modern Sikh Warriors: Militants, Soldiers, Citizens. Journal of Military Ethics 16: 272-85. [CrossRef]

Dube, Leela. 2001. Anthropological Explorations in Gender: Intersecting Fields. Thousand Oaks: Sage Publications.

Duncan, Martha G. 1991. A Strange Liking: Our Admiration for Criminals. University of Illinois Law Review 1991: $1-53$.

Finch-Boyer, Heloise. 2014. Lascars through the colonial lens: Reconsidering visual sources of South Asian sailors from the twentieth century. Journal for Maritime Research 16: 251-68. [CrossRef]

Flinders, Matthew, and Matthew Wood. 2015. From Folk Devils to Folk Heroes: Rethinking the Theory of Moral Panics. Deviant Behavior 36: 640-56. [CrossRef]

Frost, Heather D. 2010. Being “Brown" in a Canadian Suburb. Journal of Immigrant E Refugee Studies 8: $212-32$.

Garland, David. 2008. On the Concept of Moral Panic. Crime, Media, Culture 4: 9-30. [CrossRef]

Gilmore, David D. 1990. Manhood in the Making: Cultural Concepts of Masculinity. London: Yale University Press.

Girard, Rene. 1996. The Girard Reader. New York: Crossroad Publishing Company.

Glaser, Barney G., and Anselm L. Strauss. 1967. The Discovery of Grounded Theory. New York: Aldine Transaction.

Goode, Erich, and Nachman Ben-Yehuda. 1994. Moral Panics: Culture, Politics, and Social Construction. Annual Review of Sociology 20: 149-71. [CrossRef]

Gutmann, Mathew C. 1996. The Meanings of Macho: Being a Man in Mexico City. Berkeley: University of California Press.

Hall, Stuart, Chas Critcher, Tony Jefferson, John Clarke, and Brian Roberts. 1978. Policing the Crisis: Mugging, the State and Law and Order. London: Macmillan International Higher Education.

Hier, Sean P. 2008. Thinking Beyond Moral Panic: Risk, Responsibility, and the Politics of Moralization. Theoretical Criminology 12: 173-90. [CrossRef]

Hooks, B. 1995. Comrades in Struggle. In Men's Lives. Edited by Michael S. Kimmel and Michael M. Messner. Boston: Allyn and Bacon.

Kalra, Virinder, Raminder K Kalhon, and John Hutynuk. 2005. Diaspora and Hybridity. London: Sage Publishing.

Kooistra, Paul. 1989. Criminals as Heroes: Structure, Power \& Identity. Bowling Green: Bowling Green State University Popular Press.

Lusane, Clarence. 1993. Rap, Race and Politics. Race E Class 35: 41-56.

Malhotra, Anshu. 2002. Gender, Caste, and Religious Identities: Restructuring Class in Colonial Punjab. New York: Oxford University Press.

McCorkle, Richard C., and Terance D. Miethe. 1998. The Political and Organizational Response to Gangs: An Examination of a Moral Panic" in Nevada. Justice Quarterly 15: 41-64. [CrossRef]

Messerschmidt, James W. 1997. Crime as Structured Action: Gender, Race, Class, and Crime in the Making. Thousand Oaks: Sage Publications, Inc.

Mooney, Nicola. 2010. Lowly Shoes on Lowly Feet: Some Jat Sikh Women's Views on Gender \& Equality. In Sikhism and Women: History, Texts and Experience. Edited by Doris R. Jakobsh. Delhi: Oxford University Press, pp. 156-86.

Mooney, Nicola. 2013. The Yeoman Jats of Punjab: Time, Expertise, and the Colonial Construction of Jat Sikh Identity. Anthropolgica 55: 277-90. 
Morrell, Robert. 1998. Of Boys and Men: Masculinity and Gender in Southern African Studies. Journal of Southern African Studies 24: 605-30. [CrossRef]

Pearce, Jeff. 2009. Gangs in Canada. Wetaskiwin: Quagmire Press, Ltd.

Purewal, Shinder. 2012. The Evolution of Sikh Secessionist Movement in Western Liberal Democracies. International Journal of Business and Social Science 3: 107-13.

Razavy, Maryam. 2006. Sikh Militant Movements in Canada. Terrorism and Political Violence 18: 79-93. [CrossRef]

Rios, Victor M. 2011. Punished: Policing the Lives of Black and Latino Boys. New York: New York University Press.

Shek, Yen Ling. 2007. Asian American Masculinity: A review of the literature. The Journal of Men's Studies 14: 379-91. [CrossRef]

Singh, Milan, and Anita Singh. 2008. Diaspora, Political Action, and Identity: A Case Study of Canada's Indian diaspora. Diaspora: A Journal of Transnational Studies 17: 149-71. [CrossRef]

St. Cyr, Jenna L. 2003. The Folk Devil Reacts: Gangs and Moral Panic. Criminal Justice Review 28: 26-46. [CrossRef] Thangaraj, Stanley. 2012. Playing through Differences: Black-White Racial Logic and Interrogating South Asian American Identity. Ethnic and Racial Studies 35: 988-1006. [CrossRef]

Todd, Douglas. 2012. Largest Sikh Population in North America Struggles with Suspicion. The Vancouver Sun. Available online: https://vancouversun.com/news/staff-blogs/largest-sikh-community-in-north-americashocked-at-massacre/ (accessed on 18 January 2020).

Ungar, Sheldon. 2001. Moral Panic Versus the Risk Society: The Implications of the Changing Sites of Social Anxiety. The British Journal of Sociology 52: 271-91. [CrossRef] [PubMed]

Vigil, James Diego. 2007. The Projects: Gang and Non-Gang Families in East Los Angeles. Austin: University of Texas Press.

Yim, Jennifer Y., and Ramaswami Mahalingam. 2006. Culture, Masculinity, and Psychological well-being in Punjab, India. Sex Roles 55: 715-24. [CrossRef]

Zatz, Marjorie S. 1987. Chicano Youth Gangs and Crime: The Creation of a Moral Panic. Contemporary Crises 11: 129-58. [CrossRef]

(C) 2020 by the author. Licensee MDPI, Basel, Switzerland. This article is an open access article distributed under the terms and conditions of the Creative Commons Attribution (CC BY) license (http://creativecommons.org/licenses/by/4.0/). 